\title{
Determinants of technical efficiency in cotton production in the southern cotton growing zone of Nigeria: A stochastic production frontier approach
}

\author{
MUYIWA SUNDAY OLATIDOYE", TAIWO ALIMI, ADEBAYO AKINBOYE AKINOLA \\ Department of Agricultural Economics, Obafemi Awolowo University, Ile-Ife.Osun State, Nigeria. Tel.: +23-480-35275825, \\ •email: sharonsam2016@gmail.com
}

Manuscript received: 22 November 2018. Revision accepted: 29 December 2018.

\begin{abstract}
Olatidoye MS, Alimi T, Akinola AA. 2018. Quality assessment of the physicochemical properties of vermiwash produced from different sources during successive storage periods. Asian J Agric 2: 58-63. This study investigated socio-economic factors and estimated the technical efficiency indices and factors influencing technical efficiency of sampled cotton farmers in the southern cotton growing zone of Nigeria. A multistage sampling technique was employed to select a total sample of 300 cotton farmers. The study made use of only primary data which was collected through the aid of a well-structured questionnaire. The data were analyzed using descriptive statistics and stochastic frontier production parametric model. The results of the descriptive statistics showed that majority $(83 \%)$ of the cotton farmers in the study area were males, while the mean age of the respondents was 49 years. The average household size was 8 persons per household, and majority (69\%) of the respondents had formal education. Majority of the respondents (59\%) had no access to credit facilities, while the majority $(80.4 \%)$ of the cotton farmers had reasonable years of experience ranging between 11 and above in cotton production. Furthermore, the study found that the technical efficiency of the farmers ranges from 0.35 and 0.99 with a mean of 0.79 . This indicates ample opportunity for farmers to increase their productivity through improvement in their technical efficiency. Seed, fertilizer, pesticides, and farm size were found to be statistically significant and positively related to farmers' output while education, credit, extension contact, and farming experience of the respondents negatively influenced farmers' technical inefficiency. The farmers, therefore, need to increase their output through more intensive use of seed, land, pesticides, and fertilizers.
\end{abstract}

Keywords: Cotton, southern cotton growing zone, technical efficiency

\section{INTRODUCTION}

Many developing countries rely on agriculture to support their teeming populations. Hence, the development of policies that target increasing agricultural productivity is the governments' typical domestic reaction to the challenge of reducing poverty and increasing food security in rural areas (Moradeyo and Arene 2010). While the adoption of and dissemination of innovative farming practices eventually contributes to improvements in productivity and income (Awotide et al. 2013; Olatidoye et al. 2017), effective resource use and well-organized farm management are expected to boost their sustainability (Karimov 2013). Production efficiency means the attainment of production goals without waste. Efficiency is often used synonymously with that of productivity which relates output to input (Ajao et al. 2012). In Agriculture, the analysis of efficiency is generally associated with the possibility of farm production to attain optimal level of output from a given bundle of input at least cost. Thus, the crucial role of efficiency in increasing agricultural output has been widely recognized by policymakers and researchers alike. It is not surprising that considerable effort has been devoted to the analysis of farm-level efficiency in developing countries including Nigeria. An underlining premise behind much of this work is that farmers are not making efficient use of existing technology, then efforts designed to improve efficiency would be more cost-effective than introducing new technologies as a means of increasing agricultural output (Coelli et al. 1998; Ajao et al. 2012).

Cotton (Gossypium spp) remains by far the most important natural fiber. It ranks first followed by jute, kenaf and sisal in the world production of fibers. It represents (38.5\%) of the fiber market and it is considered a strategic commodity because of its standing as a source of rural employment and foreign exchange (Adeniji 2011). In Nigeria, prior to the oil boom, cotton was one of the main sources of foreign exchange and second largest employer of labor after the public sector (Gbadegesin and Uyovnisere 1994; Alam et al. 2013). Alam et al. (2013) submitted that in 1993, cotton output was roughly equivalent to the requirement of the textile industry. However, as of 2015, cotton production in Nigeria can only account for (29\%) of the requirement of the textile industry while the remaining $71 \%$ was imported. This was further corroborated by Olatidoye et al. (2017) that cotton production in the country has taken a downward trend as the gap between demand and supply is becoming wider and wider every year because the supply does not equate to demand.

Batterham (2000) asserted that supply is yet to satisfy the level of demand for cotton, and this has caused great concern in the textile cotton fiber supply situation in the local market and export profile in the country. Thereby 
having a declining effect in its contribution to the gross domestic product (GDP) of the country. Hence, achieving higher yields is a major concern for those involved in the entire cotton value chain. However, the price of cotton in the country is relatively fixed (there is small price change depending on the quality), thus a farmer can achieve higher margins only by increasing yields and efficiently using input resources. Unfortunately, yield numbers at the country level illustrate that cotton production has decreased since independence (USAID 2015). This decline is believed, in part, due to the inefficient use of resources. Moreover, the official statistics do not include resource data, thus making it difficult to acquire accurate information about the intensity of resource utilization in cotton production.

This study enlightens this issue in the context of frontier efficiency analysis by looking at some of the factors that are assumed to influence cotton production and empirically examining their significance.

\section{MATERIALS AND METHODS}

\section{The study area}

The study was conducted in the southern cottongrowing zone of Nigeria (Figure 1). This zone covers a land area of about 170,593 square kilometers representing (19.6\%) of the country's landmass and comprises the savannah/derived savannah vegetative zone of these seven states: Osun, Oyo, Ogun, Ondo, Edo, Kogi and Kwara (Institute of Agricultural Research (IAR), 2010). The livelihood activities of the households in the savannah and derived savannah area of this zone are predominantly farming, trading and artisans. The study area spread between latitude $6^{\circ}$ and $9^{\circ} \mathrm{N}$ and longitude $2^{\circ} 30^{\prime}$ and $6^{\circ} 30^{\prime} \mathrm{E}$ constituting 36 Local Government Areas (LGAs) with a combined human population of about 32,243,222 (NPC 2006). The area is characterized by sandy-loam soil type and tropical climate, with average annual rainfall ranging between $1250 \mathrm{~mm}$ and $1850 \mathrm{~mm}$, almost evenly distributed throughout the wet season while temperature varies between $21^{\circ} \mathrm{C}$ and $29^{\circ} \mathrm{C}$. The study area experiences rainfall for approximately eight months (March-October) and usually four months (November-February) of dry season each year (FAO 2013). Agriculture provides income for about $(75 \%)$ of the populace with notable food crop production including yam, maize, cassava, and rice while the notable non-food crop in the area is cotton (Adeniji 2011). The existence of good soil factors and favorable climatic conditions ensure continuous and sustainable cultivation of these crops coupled with their proven high return on investment (Olatidoye et al. 2017). Figure 1 is the map of Nigeria showing the cotton growing states and their respective zonal classifications.

\section{Sampling procedure, data collection and sample size}

A multistage sampling technique was employed using a well-structured questionnaire in selecting the respondents. The first stage was the purposive selection of two states
(Oyo and Ogun States) out of the seven, constituting the southern cotton growing zone based on the predominance and almost near equal proportions of registered cotton farmers, 315 and 335 respectively, in these two states. The second stage also involved the purposive selection of three Local Government Areas (LGAs) from each of the two States also based on the predominance/scale of production of the cotton farmers in these areas. The third stage was the random selection of five villages in each of the LGAs, while the fourth stage was the selection of ten cotton farmers from each of the villages using simple random sampling technique to give a total of 300 sampled respondents. Primary data was only used for this study.

\section{Analytical technique}

The study made use of descriptive statistics and stochastic production frontier (SPF) approach to analyze the socio-economic characteristics and estimate the efficiency indexes, respectively, of cotton farmers in the study area. The SPF, a parametric model, was used in estimating technical efficiency scores of cotton production as well as the factors influencing efficiency levels since it gives better results, allows for the measurement of random errors such as inefficiencies of production, statistical noise measurement and the confidence of the results is much higher than from non-parametric models (Ajao et al. 2012). The frontier production function was specified by the Cobb-Douglas Stochastic Production Function including all the explanatory variables. Following Battese and Coelli (1995), a one stage procedure was employed given away the biases of the two steps potential estimation procedure. The model's basic structure is as specified below:

$\mathrm{Y}_{i}=f\left(\mathrm{X}_{\mathrm{i}}, \beta\right) \mathrm{e}^{\mathrm{v}-\mathrm{u}}$

Where:

$Y_{i}=$ Output of the $i^{\text {th }}$ farm

$\mathrm{X}_{\mathrm{i}}=$ Quantity of input used.

$\beta=$ Scalar parameter (vector) to be estimated,

$\mathrm{e}_{\mathrm{i}}=$ error term $=\mathrm{V}_{\mathrm{i}}-\mathrm{U}_{\mathrm{i}}=$ composite error term

Hence, the technical efficiency model may be explicitly expressed as:

$\operatorname{LnY}=\beta_{0}+\beta_{1} \operatorname{LnX}_{1}+\beta_{2} \operatorname{LnX}_{2}+\beta_{3} \operatorname{LnX} X_{3}+\beta_{4} \operatorname{LnX}_{4}+$ $\beta_{5} \operatorname{Ln} X_{5}+\mathrm{V}_{\mathrm{i}-} \mathrm{U}_{\mathrm{i}}$

Where:

$\mathrm{Ln}=$ natural logarithm

$Y_{i}=$ output of cotton from the $i^{\text {th }}$ farmer $(\mathrm{kg})$

$\mathrm{X}_{1}=$ quantity of seed $(\mathrm{kg})$

$\mathrm{X}_{2}=$ quantity of fertilizer used $(\mathrm{kg})$

$\mathrm{X}_{3}=$ quantity of pesticides used (litre)

$\mathrm{X}_{4}=$ total labour used (man day)

$\mathrm{X}_{5}=$ farm size (Hectares)

$\beta_{1}-\beta_{5}=$ regression coefficients ;

$\mathrm{V}_{\mathrm{i}}=\mathrm{A}$ random variable in production that accounts for the random variation is output by factors beyond the control of farmers. 


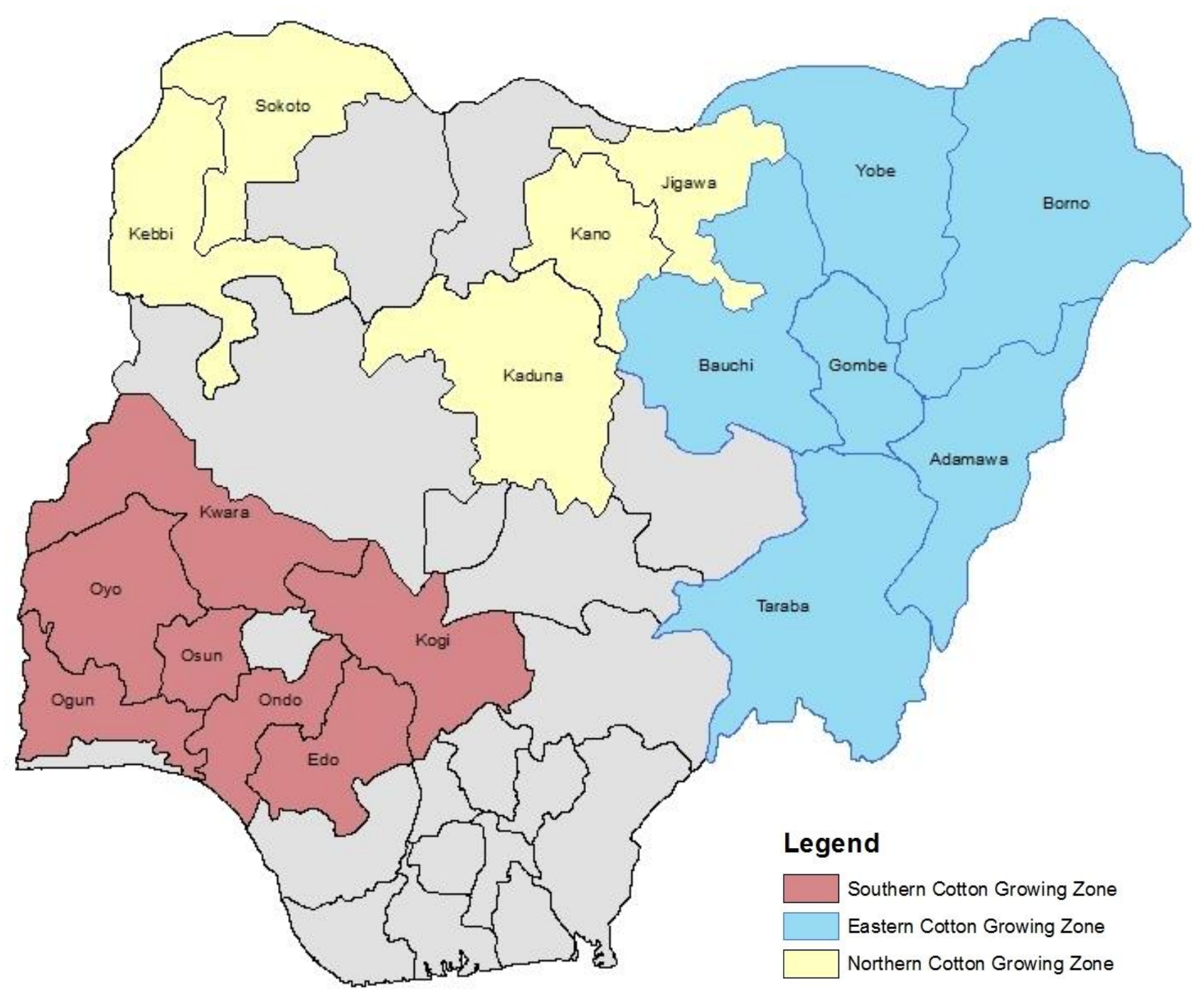

Figure 1. Map of Nigeria showing the cotton growing zones.

$\mathrm{U}_{\mathrm{i}}=$ Technical inefficiency effects independent of $\mathrm{V}_{\mathrm{i}}$, and half normal distribution with zero mean and constant variance $\left(\sigma^{2} u_{i}\right)$.

$\beta_{0}=$ intercept

The technical inefficiency effects, $\mathrm{U}_{\mathrm{i}}$ is defined by:

$\mathrm{U}_{\mathrm{i}}=\delta_{\mathrm{o}}+\delta_{1} \mathrm{Z}_{1 \mathrm{i}+} \delta_{2} \mathrm{Z}_{2 \mathrm{i}}+\delta_{3} \mathrm{Z}_{3 \mathrm{i}}+\delta_{4} \mathrm{Z}_{4 \mathrm{i}}+\delta_{5} \mathrm{Z}_{5 \mathrm{i}}+\delta_{6} \mathrm{Z}_{6 \mathrm{i}}+\delta_{7} \mathrm{Z}_{7 \mathrm{i}}$

Where:

$\mathrm{Z}_{1}=$ Age of farmer (years)

$Z_{2}=$ level of education of farmer (years)

$\mathrm{Z}_{3}=$ access to credit

$Z_{4}=$ Household size

$\mathrm{Z}_{5}=$ Membership of cooperative

$\mathrm{Z}_{6}=$ Extension contact

$\mathrm{Z}_{7}=$ Farming experience (years)
Cotton output is expected to be influenced positively by seed, fertilizer. pesticides, labor and farm size; while all the efficiency factors are expected to be negatively signed.

\section{RESULTS AND DISCUSSION}

The socio-economic/demographic characteristics investigated included: age, gender, household size, education, membership of association, experience in cotton production, access to credit, and extension contact. The results are presented in Table 1 . The results showed that the mean age of the cotton farmers in the study area was 49 years, implying that cotton farming in the study area is embraced predominantly by young and middle-aged men which are strong, agile, and active and can participate adequately in farming activities. The distribution of the respondents by gender, showed that majority $(83 \%)$ were males. This shows the dominance of male farmers in cotton 
farming in the study area. The household size distribution of the respondents showed that the mean household size was 8 persons per household, thus implying that there is appreciable number of family labor supply to accomplish various farm operations. The mean years of education were 11 years, suggesting that many cotton farmers in the study area had secondary education. The implication of this is that the costs of obtaining new technical and related information by the farmers will be reduced substantially when they can read and understand published materials and simplified farm journals which are increasingly becoming the modern vehicle of disseminating information. The distribution of members of association shows that majority $(60.4 \%)$ of the respondents belonged to Cotton Farmers' Association (CFA). Table 1 further revealed that majority of the cotton farmers $(52.3 \%)$ have been in cotton production between 11-15 years, with the mean years of experience being 13 years. About (60\%) of the respondents had no access to credit facilities with extension service access being available to (44\%) of the sampled farmers while about $(56 \%)$ had no extension contacts.

\section{Estimate of stochastic frontier production parameters}

The maximum likelihood estimate of the Stochastic Production function for cotton farmers is presented in Table 2. There was presence of technical inefficiency effects in cotton production, as confirmed by a high significant gamma $(\gamma=0.72)$ for the cotton farmers. This implies that about (72\%) variations in the maximum output among farmers in the study area were due to inefficiencies on the part of the farmers rather than random variability. Also, the significance of sigma-squared $\left(\sigma^{2}=1.25\right)$ at 1 percent for the cotton farmers shows that the Cobb Douglas Stochastic Production Function which is estimated with inefficiency effects fits the data better than the conventional production model.

The results in Table 2 further revealed that the estimated coefficients of all parameters of production function were positive in compliance with apriori expectations. Seed, fertilizer, pesticides, and farm size were positively significant at $(5 \%)$ level of probability. Hence, these variables were important determinants of yield/output in cotton production in the study area. The average technical efficiency for the farmers was 0.789 , implying that on average the respondents can obtain $(79 \%)$ of potential output from a given mixture of production inputs. Thus, in the short run, there is minimal scope $(21 \%)$ of increasing the efficiency of the cotton farmers.

The estimated coefficient for seed was 0.195 , which is positive and statistically significant at $(5 \%)$ level. The estimated 0.195 elasticity of seed implies that increasing seed by $(100 \%)$ will increase cotton output by 19.5 . The significance of seed quantity is, however, since seed determines to a large extent the output obtained. If correct seed rates and quality seed are not used, output will be low even if other inputs are in abundance. This agrees with the findings of Neba et al. (2010) and Alam et al. (2013). The production elasticity of output with respect to quantity of fertilizer was 0.4 which is positive and statistically significant at $(5 \%)$ level. This implies that a $(1 \%)$ increase in fertilizer will increase cotton output by $(0.35 \%)$. The coefficient of fertilizer also has the highest value. This indicated that fertilizer devoted to cotton production was the most important input to which output was responsive because it has the highest elasticity. Hence, intensifying the usage of fertilizers and at the recommended dosage will increase the yield/output of cotton. This also agrees with the finding of Adeniji (2011). The coefficient of farm size was also positively significant at $(5 \%)$ level. This implies that a $(1 \%)$ increase in the hectarage of cotton cultivated will increase output by 0.125 . It also implies that as the farm size increases, technical efficiency of the cotton farmers also increases. This corroborated the findings of Ajagbe (2012) and Alam et al. (2013), who submitted that small farm holders are technically inefficient, and that efficiency increases as the farm size increases. The same thing goes for other factors. Hence, an increase in the quantity/quality of these factors in cotton production would result in increase in output.

Table 1. Socio-economic characteristics of cotton farmers in the southern cotton growing zone of Nigeria.

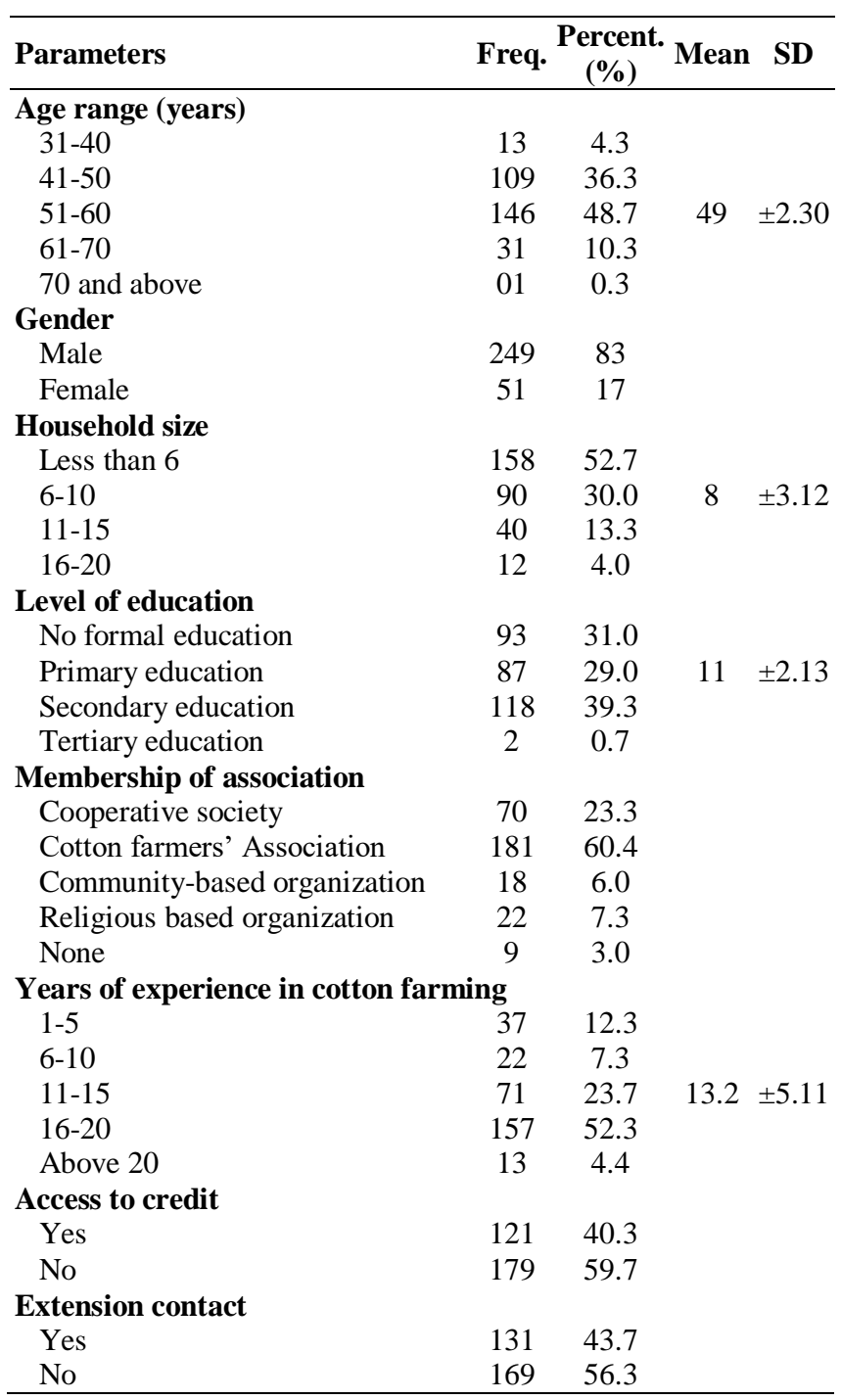

Note: SD: Standard Deviation 
The determinants of technical efficiency in cotton production as presented in Table 2 shows that the coefficient of household size was negative but insignificant at $(5 \%)$ probability level. Education showed a negative relationship with technical inefficiency and is significant at $(5 \%)$ level. The negative coefficient of education reveals that the level of education results in reduction in technical inefficiency of cotton farmers. This is because education sharpens managerial input and leads to a better assessment of the importance and complexities of good decisions in farming. This is in accordance with a priori expectation and agrees with the findings of Adzwala et al. (2013).

The coefficient for extension contact was negative and significant at $(5 \%)$ level. Access to extension services increases the level of cotton farmers' availability to information about technical aspects of crop technologies that play an important role in increasing farm-level efficiency. Furthermore, farmers who are members of extension-related organizations exhibit higher levels of efficiency. This agrees with Kehinde and Awotide 2012. The coefficient of cooperative membership was positive and significant at (1\%) level. This was contrary to a priori expectation as reported by several authors including Alam et al. (2013) and Odedokun (2014). The reasons might be that although farmers belong to a cooperative association, they do not derive much benefit from their membership, but rather tie down their resources and end up being used in unprofitable ventures. The coefficient for farming experience was negative and significant at (5\%). This shows that it increases technical efficiency and decreases technical inefficiency. This was perhaps due to their ability to draw on experience to suit their farming condition. This finding agrees with Neba et al. (2010) and Adzwala et al. (2013). The coefficient of access to credit was negative and significant at $1 \%$ level. This is in accordance with a priori expectation because credit is believed to increase crop area, more input application, and more yields (Adeyemo et al. 2010). The coefficient of household size was negative, although not significant. This shows that increase in household size decreases technical inefficiency. The more the household size, the more availability of family laborers to carry out various farm operations. This agrees with the findings of Kehinde and Awotide (2012).

The returns to scale were 0.81 (Table 3 ) which was less than one, thus indicating that the cotton farmers were producing in the region of positive decreasing return to scale (stage II) of production process where every farmer strives to maximize output and minimize cost of production. The results also show that if all the inputs included in the production function model are increased by $(1 \%)$, cotton output will increase by $(0.81 \%)$.

\section{Frequency distribution of technical efficiency estimates of cotton farmers}

Technical efficiency score shows the ability of a firm to obtain maximum output from the given inputs and technology. The estimates of technical efficiency of the cotton farmers were as presented in Table 4.
Table 2. Estimated determinants of technical efficiency of cotton farmers

\begin{tabular}{|c|c|c|c|c|}
\hline Variables & $\begin{array}{l}\text { Para- } \\
\text { meter }\end{array}$ & Coefficient & $\begin{array}{c}\text { Standard } \\
\text { error }\end{array}$ & T-ratio \\
\hline Constant & $\beta_{0}$ & 8.7456 & 0.7889 & 11.0858 \\
\hline Seed & $\beta_{1}$ & $0.1953 * *$ & 0.0551 & 3.5445 \\
\hline Fertilizer & $\beta_{2}$ & $0.3469 * *$ & 0.1042 & 3.3292 \\
\hline Pesticides & $\beta_{3}$ & $0.1257^{*}$ & 0.0553 & 2.2731 \\
\hline Labor & $\beta_{4}$ & 0.0215 & 0.0304 & 0.7072 \\
\hline Farm size & $\beta_{5}$ & $0.1247 * *$ & 0.0316 & 3.9462 \\
\hline Constant & $\delta_{0}$ & 0.8193 & 0.1980 & 4.1378 \\
\hline Age & $\delta_{1}$ & 0.0255 & 0.0237 & 1.0782 \\
\hline Education & $\delta_{2}$ & $-0.0878 *$ & 0.0407 & -2.1573 \\
\hline Access to credit & $\delta_{3}$ & $-0.1672 * *$ & 0.0510 & -3.2784 \\
\hline Household size & $\delta_{4}$ & -0.0017 & 0.0016 & -1.0625 \\
\hline $\begin{array}{l}\text { Cooperative } \\
\text { membership }\end{array}$ & $\delta_{5}$ & $0.0875^{* *}$ & 0.0119 & 7.3529 \\
\hline Extension contact & $\delta_{6}$ & $-0.0137 *$ & 0.0050 & -2.7400 \\
\hline Farming experience & $\delta_{7}$ & $-0.0331 *$ & 0.0159 & -2.0817 \\
\hline \multicolumn{5}{|l|}{ Diagnostic statistic } \\
\hline Sigma-squared & & 1.2498 & 0.0917 & 13.6293 \\
\hline Gamma & & 0.717 & 0.0577 & 12.4263 \\
\hline Log-likelihood functio & & -535.57 & & \\
\hline $\begin{array}{l}\text { Total number of } \\
\text { observations }\end{array}$ & & 300 & & \\
\hline Mean efficiency & & 0.79 & & \\
\hline
\end{tabular}

Note: $* 5 \%$ level of significance, $* * 1 \%$ level of significance.

Table 3: Elasticity of production and return to scale in cotton production.

\begin{tabular}{lcc}
\hline Variables & Parameter & Coefficient \\
\hline Seed & $\beta_{1}$ & 0.1953 \\
Fertilizer & $\beta_{2}$ & 0.3469 \\
Pesticides & $\beta_{3}$ & 0.1257 \\
Labor & $\beta_{4}$ & 0.0215 \\
Farm size & $\beta_{5}$ & 0.1247 \\
Return to scale (RTS) & & 0.81 \\
& &
\end{tabular}

Table 4. Frequency distribution of Technical efficiency estimates

\begin{tabular}{lcc}
\hline Technical efficiency & Frequency & Percentage $(\%)$ \\
\hline $0.31-0.40$ & 7 & 2.3 \\
$0.41-0.50$ & 12 & 4.0 \\
$0.51-0.60$ & 19 & 6.3 \\
$0.61-0.70$ & 73 & 24.3 \\
$0.71-0.80$ & 122 & 40.7 \\
$0.81-0.90$ & 45 & 15 \\
$0.91-100$ & 22 & 7.4 \\
Total & 300 & 100 \\
Average & 79 & \\
Std. Deviation & 10.2 & \\
Maximum & 99 & \\
Minimum & 35 & \\
\hline
\end{tabular}


The results showed that the mean technical efficiency is $(79 \%)$. This suggests that there is about $(21 \%)$ chance of increasing output without additional inputs in cotton production. This also indicates that for the average cotton farmer to achieve the technical efficiency level of the most technically efficient farmer, he/she would realize about (20.2\%) (i.e., 1-79/99) cost-saving. On the other hand, the least technically efficient farmer will have about $(64.7 \%)$ (i.e., 1-35/99) cost saving on inputs using the same technology. These results indicate a high technical inefficiency exists among the cotton farmers in the study area. Hence, there is great potential to enhance cotton productivity by improving technical efficiency of the cotton farmers, resulting in improved income, with a resultant impact on poverty reduction and wealth creation in the study area.

\section{Conclusion and recommendations}

The study has shown the distribution of technical efficiency of cotton farmers in the southern cotton growing zone of Nigeria. Farmers' specific factors like education, access to credit, frequency of extension contacts and farming experience contributed positively to technical efficiency level of the cotton farmers in the study area. Also, production inputs like seeds, fertilizer, pesticides, and farm size positively influenced cotton output. Furthermore, $72 \%$ of the variations in input use among the farmers were due to inefficiency on the part of the farmers rather than random variability. Hence, on average, technical efficiency of the cotton farmers could be increased by $21 \%$, using the current production technology.

Based on the findings of this study, it is recommended that: (i) Policies that would guarantee adequate access to credit facilities by the cotton farmers are strongly advocated. This will ensure that the farmers have enough resources for expansion. (ii) An effective extension service should be established to bridge the gap between cotton farmers and research institutions, and to create awareness about improved technologies in cotton production. (iii) Government should assist by improving the educational status of the farmers through adult education and farmers should be educated and taught effective management of the available resources through workshops, training, and seminars.

\section{REFERENCES}

Adeniji OB. 2011. Adoption of Improved Technologies for Cotton Production in Katsina State, Nigeria. [Dissertation]. Ahmadu Bello University, Zaria.

Adeyemo R, Oke JTO, Akinola AA. 2010. Economic efficiency of smallscale farmers in Ogun State, Nigeria. Trop Agric J 28 (2): 84-88.

Adzwala W, Fuseini J, Donkoh SA. 2013. Estimating the technical efficiency of cotton production in Yendi Municipality, Northern Ghana. J Sustain Dev 4 (70): 123-133.

Ajagbe FA. 2012. Analysis of access to and demand for credit by small scale entrepreneurs. Quart J Intl Agric 41 (3): 225-240.

Ajao AO, Ogunniyi LT, Adepoju AA. 2012. Economic efficiency of soybean production in Ogo-oluwa local government area of Oyo State, Nigeria. Amer J Exp Agric 2 (4): 667-679.

Alam MK, Aboki E, Gidado EH. 2013. An economic analysis of cotton production in selected local government areas of Taraba State, Nigeria. J Agric Sci 4 (1): 27-31.

Awotide BA, Karimov A, Diagne A, Nakelse T. 2013. The impact of seed vouchers on poverty reduction among smallholder rice farmers in Nigeria. J Agric Econ 8 (44): 647-658.

Battese GE, Coelli TJ. 1995. A model for technical inefficiency for panel data with application to paddy rice farmers in India. Empiric Econ 15 (20): 315-330.

Betterham R. 2000. The Chance to Change Discussion Paper by the Chief Scientist Canberra, African Summit, Abuja, Nigeria.

Coelli TJ, Rao DSP, Battese GE. 1998. An Introduction to Efficiency and Productivity Analysis. Kluwer Academic Publishers, Boston.

Coelli TJ. 1995. A Guide to Frontier, Version 4.1:a Computer Programme for Stochastic Frontier Production and Cost Function Estimation. Department of Econometrics, University of New England, Armidale, Australia.

FAO. 2013. Review of the State of World Cotton Production in 2012, by Gracia SM and Grainger RJ. FAO Cotton Technical Paper.

Gbadegesin J, Uyovnisere K. 1994. Cotton Production in Nigeria. Baraka Press and Publishers Ltd., Kaduna, Nigeria.

Institute of Agricultural Research (IAR). Samaru. Bulletin on Cotton varieties and Cotton growing zones in Nigeria. Ahmadu Bello University, Zaria. 2006.

Karimov A. 2013. Economic inefficiency and shadow prices of inputs: the case of vegetable growing farms in Uzbekistan. Procedia Econ Finan 5: 403-412.

Kehinde J, Awotide AC. 2012. Production efficiency of mechanized arable farming in Osun State, Nigeria. J Agric Technol 3 (9): 65-82.

Moradeyo AO, Arene CJ. 2010. Constraints and determinants of technical efficiency in medium scale soybean production in Benue State, Nigeria. African J Agric Res 5 (17): 2276-2280.

NPC. 2006. Provisional Results. National Population Commission. Abuja, Nigeria.

Neba C, Ngassam S, Nzomo J. 2010. The Determinants of Technical Efficiency of Cotton Farmers in Northern Cameroon. MPRA Paper No. 24814.

Odedokun VO. 2014. Economic Analysis of Cotton Production and Supply trend Estimation in Zamfara State, Nigeria. [Dissertation], Department of Agricultural Economics and Rural Sociology, Ahmadu Bello University Zaria, Nigeria.

Olatidoye MS, Ogunleye AS, Alimi T. 2017. Analysis of adoption of new cotton varieties among farmers in Osun State, Nigeria. Ife J Agric 29 (1): 33-42.

USAID. 2015. Global Cotton Production Trend. United States Agency for International Development, Washington DC. 